\title{
Application of sumac and dried whey in female broiler feed
}

\author{
F. Kheiri ${ }^{1}$, Y. Rahimian ${ }^{1}$, and J. Nasr $^{2}$ \\ ${ }^{1}$ Department of Animal Science, Faculty of Agriculture, Shahrekord Branch, Islamic Azad University, \\ Shahrekord, Iran \\ ${ }^{2}$ Department of Animal Science, Faculty of Agriculture, Saveh Branch, Islamic Azad University, Saveh, Iran \\ Correspondence to: F. Kheiri (farshid_kheiri@yahoo.com)
}

Received: 23 January 2015 - Revised: 21 April 2015 - Accepted: 6 May 2015 - Published: 21 May 2015

\begin{abstract}
The present study aimed at investigating the effects of sumac and dried whey powder on growth performance, carcass traits, intestinal morphology, microbial population, and some biochemical parameters and antibody titer against Newcastle disease of female broiler chicks. A total of 360 1-day-old female broiler chicks with an average weight of $38 \pm 0.42 \mathrm{~g}$ were randomly divided into three treatments. Each treatment was further divided into six replicates. Three treatments were used: chicks were fed by basal diet as control group, basal diet $+0.02 \%$ sumac powder (S), and basal diet $+0.02 \%$ dried whey powder (DW) for 42 days. Results showed that feed intake of chicks increased significantly in S and DW in comparison with the control group $(P<0.05)$. Body weight gain was also significantly higher in the treated groups. The serum concentration triglyceride and cholesterol of chicks decreased significantly by S and DW feeding. While low-density lipoprotein (LDL) level decreased significantly, high-density lipoprotein (HDL) levels increased in the S group. Antibody level increased titer against Newcastle disease significantly by feeding treated diet compared to the control group. Data from microbial population investigation showed that $E$. coli population decreased while Lactobacillus increased in S and DW groups. The data revealed an improvement in the body weight gain, feed conversion ratio because of increased intestinal morphology, antibody level, and some useful microbial population in female broiler chicks receiving the sumac and dried whey powder.
\end{abstract}

\section{Introduction}

Sumac (Rhus coriaria $\mathrm{L}$ ) is a plant species in the anacardiaceous family that is used as a spice and herbal medicine. Sumac is found in hot, temperate, and tropical regions worldwide (Kurucu et al., 1993). It has a long history of use by indigenous people for medicinal and other applications (Rayne and Mazza, 2007). The fruits of sumac contain flavonols, phenolic acids, hydrolysable tannins, anthocyanins, and organic acids such as malic, citric and tartaric acids $(\mathrm{Oz}-$ can and Haciseferogullari, 2004; Greathead, 2003; Jung, 1998). Sumac is used as an herbal remedy in traditional medicine because of its assumed analgesic, antidiarrheal, antiseptic, anorectic, and antihyperglycemic properties (Rayne and Mazza, 2007). Probiotics have been defined as a live microbial feed supplement that can beneficially affect the intestinal microbial balance, resulting in improved body weight gain and reduce mortality in broiler chickens. Prebiotics are defined as nondigestible, but fermentable food ingredients that beneficially affect the host by selectively stimulating the growth and activity of one or a limited number of species of probiotics bacteria in the colon (Panda et al., 2006). Symbiosis is defined as a combination of a probiotics and a prebiotics, aimed to increase the survival activity of probiotics in vivo and stimulating indigenous bifido bacteria and $\mathrm{Lac}$ tobacillus (Dughera et al., 2007). Whey, a liquid remaining from cheese or casein production, is one of the most valuable protein sources in the human food chain. In spite of its balanced nutrients, liquid whey is disposed as a waste product and dried whey that is produced from its liquid form can be used in bird diets (Aghaei et al., 2010). It is shown that dietary supplementation of whey powder linearly increases body weight gain and nitrogen retention in turkey and broiler 
chickens (Shariatmadari and Forbes, 2005). The purpose of this study was to investigate the response of broiler chicken consumption of dried whey powder as symbiotic and sumac powder as prebiotic on performance, intestinal morphology, and microbial population of Escherichia coli and Lactobacillus in the gastrointestinal tract.

\section{Materials and methods}

\subsection{Birds and diets}

All procedures used in this experiment were approved by the Department of Animal Science, Faculty of Agriculture, Shahrekord Branch, Islamic Azad University, Shahrekord, Iran. A total of 360 1-day-old Ross 308 commercial female broiler chickens with an average weight of $38 \pm 0.42 \mathrm{~g}$ were randomly distributed into three dietary treatments with six replicates each. The birds were housed in groups of 3 in 18 pens under standard conditions of temperature, humidity, and ventilation. The study was carried out in the poultry farm of Animal Science College, Shahrekord Branch, Islamic Azad University, Shahrekord, Iran, for a period of 6 weeks. The sumac was purchased from the local market, and the whey was purchased from PAK dairy company. It was ground to a fine powder and then mixed with the basal diet. The basal diet (control group) was formulated according to requirements recommended by the Ross manual (Ross, 2007) on the basis of corn, wheat, soybean meal, and soybean oil (Table 1). The three experimental treatments were the following: control group (basal diet), sumac group (basal diet $+0.02 \%$ of sumac powder (S)), and dry whey (basal diet $+0.02 \%$ of dried whey powder (DW)). In the basal diet, sand was used as neutral substance instead of sumac and dried whey powder. The chemical compositions of sumac and dried whey are shown in Table 2. Feed and fresh water were provided ad libitum during this experiment. Body weight gain, feed intake, and feed conversion rate (FCR) were calculated for the experimental period. A lighting programme of $23 \mathrm{~L}$ : 1D was used for the trial period.

\subsection{Data collection}

On day 42 , all birds were processed after a $4 \mathrm{~h}$ feed withdrawal period; two birds per pen were randomly selected and killed in a commercial slaughter house. Weight of carcass, breast, and thigh were recorded on 12 birds per treatment $(n=36)$. Carcass yield was calculated as eviscerated carcass with neck, feet, and abdominal fat pad removed, as percentage of live body weight at the time of feed withdrawal.

\subsection{Evaluation of blood parameters}

The blood samples were taken from the brachial vein from two birds per replicate and stored at refrigerator at $+4{ }^{\circ} \mathrm{C}$. Also the blood serum samples were subjected to biochemical
Table 1. Composition (measured in \%) of the experimental diets for broiler chicks.

\begin{tabular}{lrrr}
\hline Ingredients & $\begin{array}{r}0-10 \\
\text { (days old) }\end{array}$ & $\begin{array}{r}11-24 \\
\text { (days old) }\end{array}$ & $\begin{array}{r}25-42 \\
\text { (days old) }\end{array}$ \\
\hline Corn grain & 51.64 & 56.61 & 60.37 \\
Soybean meal & 37.74 & 32.30 & 27.81 \\
Wheat grain & 5 & 5 & 5 \\
Vegetable oil & 1.40 & 2.03 & 2.84 \\
Di calcium phosphate & 1.56 & 1.47 & 1.39 \\
Oyster shells & 1.17 & 1.13 & 1.08 \\
Methionine D-L & 0.30 & 0.29 & 0.27 \\
Lysine-L & 0.13 & 0.13 & 0.30 \\
Edible NaCl & 0.26 & 0.24 & 0.14 \\
Vitamin, mineral premix & 0.6 & 0.6 & 0.6 \\
Sand/sumac/whey & 0.2 & 0.2 & 0.2 \\
\hline Calculated nutrient content & & & \\
\hline ME (Kcal/Kg) & & & \\
Crude protein & 2.850 & 2.950 & 3.050 \\
Ca & 22 & 20 & 18.5 \\
Available phosphorus & 0.90 & 0.85 & 0.80 \\
Lysine & 0.45 & 0.42 & 0.40 \\
Na & 1.35 & 1.20 & 1.16 \\
Methionine + cystine & 0.16 & 0.15 & 0.15 \\
\hline
\end{tabular}

${ }^{1}$ Supplied per kilogram of feed: $7500 \mathrm{IU}$ of vitamin A, $2000 \mathrm{IU}$ vitamin D3, $30 \mathrm{Mg}$ vitamin E, $1.5 \mu \mathrm{g}$ vitamin B12, $2 \mathrm{Mg}$ B6, $5 \mathrm{Mg}$ vitamin $\mathrm{K}, 5 \mathrm{Mg}$ vitamin B2, $1 \mathrm{Mg}$ vitamin $\mathrm{B} 1,40 \mathrm{Mg}$ nicotinic acid, $160 \mu \mathrm{g}$ vitamin biotin, $12 \mathrm{Mg}$ calcium pantothenate, $1 \mathrm{Mg}$ folic acid $20 \mathrm{Mg} \mathrm{Fe}, 71 \mathrm{Mg} \mathrm{Mn}, 100 \mu \mathrm{g} \mathrm{Se}, 37 \mathrm{Mg} \mathrm{Zn}, 6 \mathrm{Mg} \mathrm{Cu}, 1.14 \mathrm{Mg} \mathrm{I}, 400 \mu \mathrm{g} \mathrm{Cu}$.

analysis for cholesterol, triglycerides, high-density lipoprotein (HDL) and low-density lipoprotein (LDL) by Pars Azmoon commercial kits (Ellefson and Garaway, 1967).

\subsection{Detection of antibody titer to ND}

Using hemagglutination inhibition test (HI) according to Beard (1989) with chicken red blood cells and four units of NDV (Newcastle disease vaccine) antigen, then geometric mean titers were calculated.

\subsection{Microbial count}

The internal organs were removed after slaughter. About $7 \mathrm{~cm}$ from the length of the ileum was sampled to determine the microbial population. Also $1 \mathrm{~g}$ of ileum content was used to make 10 -fold dilution using buffered peptone water and then $0.1 \mathrm{~mL}$ of the appropriate ileum dilution was spread on Lactobacillus MRS ${ }^{1}$ Agar-Hi Media Laboratories to detect lactic acid bacteria and $\mathrm{VRBA}^{2}$ (Violet Red Bile Agar) to

\footnotetext{
${ }^{1}$ Lactobacilli MRS is based on the formulation of de Man, Rogosa and Sharpe. www.himedialabbs.com M6411-500G.

${ }^{2} \mathrm{Hi}$ Media Laboratories Pvt. Ltd. A-516, Swastik Disha Business Park, Via Vadhani Ind. Est., LBS Marg, Mumbai400086, India, customer care no.: 022-61471919; email: techhelp@himedialabs.com.
} 
Table 2. Chemical composition of the sumac and dried whey (\% dry matter).

\begin{tabular}{lrrrrr}
\hline Components & Moisture (\%) & Protein (\%) & Fat (\%) & Fiber (\%) & Ash (\%) \\
\hline Sumac & 12 & 0.8 & 2.25 & 27 & 4.65 \\
Whey & 94 & 1.1 & 2.50 & 0 & 2.40 \\
\hline
\end{tabular}

detect $E$. coli form. The cultures of Lactobacillus and E. coli bacteria were made an aerobically form. The plates were incubated at $37.5^{\circ} \mathrm{C}$ for $48 \mathrm{~h}$. After counting the number of colonies in each plate, the number so obtained was multiplied by inverse of the dilution and the result was stated as the number of colony forming unit (cfu) in $1 \mathrm{~g}$ of the sample (Downes and Ito, 2001).

\subsection{Histomorphometric examination of small intestine}

The histomorphometric examination was performed by light microscopy, and the measurement was done using public domain image analysis software (Image J, National Institute of Mental Health, Bethesda, MD, USA) (Rezaian, 2006).

\subsection{Statistical analysis}

Data analysis was performed by using the general linear model procedure and the comparison of means was made through Duncan's multiple range test by using SAS 9.1 software (SAS, 2004).

\section{Results}

Data from this study showed that feeding of S and DW diets significantly increased body weight gain and reduced feed intake of chicks $(P<0.05)$ compared to the control diet. The feed conversion ratio of female broiler chicks significantly $(P<0.05)$ improved by feeding sumac and whey powder (Table 3$)$.

The triglyceride, cholesterol, and LDL level decreased significantly in the treated groups compared to control group while $\mathrm{S}$ group had the lowest level of triglyceride, cholesterol, and LDL blood plasma. The antibody titer against Newcastle vaccine disease in control and treated groups is given in Table 4. Antibody titer was significantly higher $(P<0.05)$ when female broiler chicks were fed with $\mathrm{S}$ and DW diets. It was determined that sumac and dried whey had significant $(P<0.05)$ effects on antibody titer against Newcastle disease vaccine compared to control group (Table 4).

It was showed that sumac and dried whey had significant $(P<0.05)$ effects on intestinal microbial population compared to control group (Table 5). Data showed that $E$. coli population decreased while Lactobacillus population increased significantly in DW and S compared with the control group, respectively $(P<0.05)$.
Table 3. The effect of sumac and whey powder on growth performance of female broiler chicks.

\begin{tabular}{lrrr}
\hline Treatments & $\begin{array}{r}\text { Feed intake } \\
\left(\mathrm{g} \mathrm{day}^{-1}\right)\end{array}$ & $\begin{array}{r}\text { Body weight gain } \\
\left(\mathrm{g} \mathrm{day}^{-1}\right)\end{array}$ & FCR \\
\hline Control & $114.81^{\mathrm{a}}$ & $52.88^{\mathrm{b}}$ & $2.11^{\mathrm{a}}$ \\
$\mathrm{S}$ & $109.81^{\mathrm{b}}$ & $55.06^{\mathrm{a}}$ & $1.99^{\mathrm{c}}$ \\
$\mathrm{DW}$ & $109.32^{\mathrm{c}}$ & $54.12^{\mathrm{a}}$ & $2.02^{\mathrm{b}}$ \\
\hline $\mathrm{SEM}^{1}$ & 0.131 & 0.951 & 0.101 \\
\hline
\end{tabular}

${ }^{1}$ Standard error of the means. Column values with same superscript or no superscript are not significantly different $(P>0.05)$. Control group $=$ basal diet, $\mathrm{S}=$ basal diet $+0.02 \%$ of sumac powder and $\mathrm{DW}=$ basal diet $+0.02 \%$ of dried whey powder.

The effects of sumac and whey powder on some carcass traits of female broiler chicks are given in Table 6. The results showed that using sumac and whey powder already reduced abdominal fat and bursa of Fabricius percentage. These treatments also significantly increased liver and spleen percentage $(P<0.05)$.

The effect of sumac and dried why powder supplementation on the histology of intestines is given in Table 7. As results reveal, we demonstrated that mucosa, muscularis, serosa, and total length increased significantly in S and DW compared to control group. Also female broiler chicks fed with dried whey powder had thicker mucosa, muscularis, serosa, and total than other groups $(P<0.05)$.

\section{Discussion}

Recent research and development of symbiotic products have been increasingly focused on functional benefits including resistance to gastrointestinal bacterial infection and improved immune status in broiler chicks. The consumption of a probiotic in combination with a suitable prebiotic (symbiotic) can result in synergistic effects (Zanoni et al., 2008). Hosseini Mansoub (2012) showed that using different levels of sumac had significant effects $(P<0.05)$ on feed intake, weight gain, body weight, and feed conversion ratio of broiler chickens. According to Ghasemi et al. (2014) the improvements in body weight gain and feed conversion ratio are due to the active materials (cinnamaldehyde and eugenol) found in sumac, causing greater efficiency in the utilization of feed, resulting in enhanced growth. Hosseini Mansoub (2012) found that antimicrobial substances present in sumac and cinnamon can reduce the harmful bacteria pop- 
Table 4. The effect of sumac and whey powder diets on some blood biochemical parameters and antibody titer against Newcastle vaccine disease of female broiler chick.

\begin{tabular}{lrrrrr}
\hline Treatments & Triglyceride $\left(\mathrm{mg} \mathrm{dl}^{-1}\right)$ & Cholesterol $\left(\mathrm{mg} \mathrm{dl}^{-1}\right)$ & $\mathrm{HDL}\left(\mathrm{mg} \mathrm{dl}^{-1}\right)$ & $\mathrm{LDL}\left(\mathrm{mg} \mathrm{dl}^{-1}\right)$ & $\mathrm{HI}\left(\log _{2}\right)$ \\
\hline Control & $71.35^{\mathrm{a}}$ & $132.42^{\mathrm{a}}$ & $58.16^{\mathrm{b}}$ & $70.11^{\mathrm{a}}$ & $3.97^{\mathrm{c}}$ \\
$\mathrm{S}$ & $69.26^{\mathrm{c}}$ & $130.10^{\mathrm{c}}$ & $60.11^{\mathrm{a}}$ & $68.19^{\mathrm{c}}$ & $4.48^{\mathrm{a}}$ \\
DW & $70.11^{\mathrm{b}}$ & $131.14^{\mathrm{b}}$ & $59.55^{\mathrm{b}}$ & $69.12^{\mathrm{b}}$ & $4.31^{\mathrm{b}}$ \\
\hline SEM & 0.111 & 0.316 & 0.455 & 0.314 & 0.498 \\
\hline
\end{tabular}

Column values with same superscript or no superscript are not significantly different $(P>0.05)$.

Table 5. The effect of sumac and whey powder diets on intestinal microbial population of female broiler chicks.

\begin{tabular}{lrr}
\hline Treatments & E. coli $\left(\mathrm{CFU} \mathrm{g}^{-1}\right)$ & Lactobacillus $\left(\mathrm{CFU} \mathrm{g}^{-1}\right)$ \\
\hline Control & $7.14^{\mathrm{a}}$ & $4.56^{\mathrm{c}}$ \\
S & $6.88^{\mathrm{b}}$ & $5.13^{\mathrm{a}}$ \\
DW & $6.83^{\mathrm{b}}$ & $5.19^{\mathrm{a}}$ \\
\hline SEM & 0.363 & 0.521 \\
\hline
\end{tabular}

Column values with same superscript or no superscript are not significantly different $(P>0.05)$.

ulations in the gastrointestinal tract and improve the levels of absorbed amino acids. Aghaei et al. (2010) showed that using dried whey in laying hen diet had significant effects $(P<0.05)$ on feed conversion ratio, and $5 \%$ dried whey diet had least feed conversion ratio while adding probiotic did not affect feed conversion ratio in laying hens. Sumac, which has hypocholesterolemic effects that lead to d-limonene (1-methyl-4-,1-methyletheny 1-cyclohexane), is a monocyclic monoterpene component. The hypocholesterolemic action of sumac is possibly related to its polyphenolic components. Poly phenols have been shown to depress the reverse-cholesterol transport, reduce the intestinal cholesterol absorption and even increase bile acid excretion (Jung, 1998). Also free gallbladder acids attach to bacteria and fibers and this can increase the excretion of them. This is consistent with the well-observed effect of herbs on lowering blood cholesterol level. Sumac extracts have been found to have antimicrobial, hypoglycemic, and antioxidant activities (Hosseini Mansoub, 2012). These results on biochemical blood parameters were not in accordance with Golzadeh et al. (2012), who declared that there was no significant difference between the treatments for plasma triglyceride, HDL, and LDL concentrations. However, they were in similar to the results of Hosseini Mansoub (2012), who showed that the serum total cholesterol, triglycerides, and LDL concentration were significantly reduced and the concentration of serum HDL was significantly induced in treatment groups compared to the control group $(P<0.05)$. Concerning humeral immune response, high doses of symbiotic improve the HI antibody titers for NDV compared to that of the control group. These results are in agreement with Ashgan and Samah (2011), who showed a high concentration of symbiotic improves the antibody response to NDV and infectious bronchitis virus vaccines. Researchers suggested that sumac and probiotic can control microbial growth by acting on the microflora's biochemical processes such as protein synthesis or inhibiting the elongation of Methanobacterium and Escherichia coli, or by reducing lactic acid producing bacteria in the gastrointestinal tract (Guvenc and Koyuncu, 1994). Jung (1998) indicated that sumac is effective against both gram-positive and gram-negative bacteria, while it is more effective on gram-positive than gram-negative microorganisms. Fairchild et al. (2001) and Spring et al. (2000) reported that the use of probiotics in the ration reduces the total population of $E$. coli forms in the intestinal lumen. Rada et al. (1999) found that the use of Lactobacillus salivary in the chicken's diet can reduce the coliform bacteria population significantly as compared with the control treatment by reducing the intestinal $\mathrm{pH}$ level. Chung and Day (2004) showed that lactose in dried whey cannot be digested or absorbed so fermented by lactic acid bacteria, production of lactic acid and reduction in the $\mathrm{pH}$ and multiplication of pathogenic bacteria. Despite of this, Yang et al. (2007) observed no change in the gastrointestinal microbial flora by adding probiotic similar to dried whey diet. The probiotic microorganisms prevent the growth of pathogenic bacteria in the intestinal environment by production of acids, such as acetic acid and lactic acid and other components (Fuller, 1989). Zavaragh (2011) found that there is a possibility that gathering these antimicrobial herbs caused a remarkable decrease in the amount of intestine microbial colony. In this study sumac and whey powder reduced abdominal fat and bursa of Fabricius percentage similar to Hosseini Mansoub (2012), who showed that use of sumac had decreased abdominal fat and increased gizzard and liver weight. Langhout (2000) showed that herbal plants could stimulate the digestion system in poultry, improve the function of the liver, and increase the pancreatic digestive enzymes. Enhancement of the metabolism of herbal plants, carbohydrates and proteins in the major organs would increase growth rate of these organs. Majewska et al. (2009) showed that use of whey increased liver weight percentage and decreased heart, abdominal fat, and gizzard weight percentage in broiler chickens. 
Table 6. The effect of sumac and whey powder diets on carcass traits (\%) of female broiler chicks.

\begin{tabular}{lrrrrrrr}
\hline Treatments & Abdominal fat & Spleen & Gizzard & Liver & Bursa of Fabricius & Breast & Thighs \\
\hline Control & $4.72^{\mathrm{a}}$ & $0.171^{\mathrm{c}}$ & $3.30^{\mathrm{c}}$ & $2.91^{\mathrm{c}}$ & $0.321^{\mathrm{a}}$ & $26.12^{\mathrm{b}}$ & $22.22^{\mathrm{c}}$ \\
S & $4.12^{\mathrm{c}}$ & $0.201^{\mathrm{a}}$ & $3.65^{\mathrm{a}}$ & $3.08^{\mathrm{b}}$ & $0.245^{\mathrm{b}}$ & $26.72^{\mathrm{a}}$ & $23.14^{\mathrm{a}}$ \\
DW & $4.34^{\mathrm{b}}$ & $0.186^{\mathrm{b}}$ & $3.44^{\mathrm{b}}$ & $3.23^{\mathrm{a}}$ & $0.287^{\mathrm{b}}$ & $6.38^{\mathrm{b}}$ & $22.94^{\mathrm{b}}$ \\
\hline SEM & 0.265 & 0.094 & 0.212 & 0.122 & 0.171 & 0.102 & 0.126 \\
\hline
\end{tabular}

Column values with same superscript or no superscript are not significantly different $(P>0.05)$.

Table 7. The effect of sumac and whey powder diets on intestinal characteristics of female broiler chicks.

\begin{tabular}{lrrrrrrr}
\hline Treatments & $\begin{array}{r}\text { Mucosa } \\
(\mu \mathrm{m})\end{array}$ & $\begin{array}{r}\text { Muscularis } \\
(\mu \mathrm{m})\end{array}$ & $\begin{array}{r}\text { Serosa } \\
(\mu \mathrm{m})\end{array}$ & $\begin{array}{r}\text { Total }^{*}(\mu \mathrm{m}) \\
(\text { number })\end{array}$ & $\begin{array}{r}\text { Goblet cells } \\
(\mu \mathrm{m})\end{array}$ & $\begin{array}{r}\text { Epithelium } \\
(\mu \mathrm{m})\end{array}$ \\
\hline Control & $114^{\mathrm{c}}$ & $12.10^{\mathrm{c}}$ & $7.10^{\mathrm{c}}$ & $133.20^{\mathrm{c}}$ & $4.38^{\mathrm{c}}$ & $2.72^{\mathrm{b}}$ & $18.78^{\mathrm{b}}$ \\
S & $116^{\mathrm{b}}$ & $12.75^{\mathrm{b}}$ & $7.45^{\mathrm{b}}$ & $136.20^{\mathrm{b}}$ & $5.34^{\mathrm{b}}$ & $3.56^{\mathrm{a}}$ & $20.11^{\mathrm{a}}$ \\
DW & $119^{\mathrm{a}}$ & $13.25^{\mathrm{a}}$ & $8.15^{\mathrm{a}}$ & $140.40^{\mathrm{a}}$ & $5.65^{\mathrm{a}}$ & $3.60^{\mathrm{a}}$ & $21.08^{\mathrm{a}}$ \\
\hline SEM & 0.645 & 0.134 & 0.091 & 0.364 & 0.621 & 0.178 & 0.698 \\
\hline
\end{tabular}

${ }^{*}$ Total $=$ mucosa + muscularis + serosa; column values with same superscript or no superscript are not significantly different $(P>0.05)$.

The digestive tract is influenced by some herbal plant, which has an exact effect on intestinal activity and structural of intestinal villi in broiler chicks (Rafiee et al., 2014). Samanya and Yamauchi (2002) demonstrated that by increasing villus height and absorptive surface area absorptive function, digestive performance will increase. In fact some growth promoters in herbs can modify brush border enzymes and the nutrient transport systems. Miles et al. (2006) showed that the reduction of the inflammatory reactions at the intestinal mucosa can increase the villus height and secretion of enzymes, digestion performance, and absorption of nutrients by the them. Ghasemi et al. (2014) demonstrated that the use of sumac extract affects intestinal characteristics such as villus height, crypt depth, villus width, epithelium layer, and goblet cells. Szczurek et al. (2013) showed that the overall effect of feeding duration with the whey containing diets was seen only for breast meat yield and relative spleen weight. Their value increased $(P<0.05)$ as feeding duration increased from 1-7 to 1-42 days. The results of current study are in agreement with Ghasemi et al. (2014), Rafiee et al. (2014), and Samanya and Yamauchi (2002). It can be hypothesized that, in the current experiment, increased integrity of the intestinal tract associated with a greater villi height and surface area after whey supplementation resulted in improved live performance and carcass traits of broiler chickens.

\section{Conclusions}

It is concluded that dietary supplementation of sumac $(0.02 \%)$ and dried whey powder $(0.02 \%)$ can reduce triglyceride, cholesterol, and LDL in plasma of female broiler chicks at 42 days of age. According to our results, the use of dried whey and sumac can reduce the intestinal $\mathrm{pH}$ and provide a good environment for Lactobacillus growth and limited multiplication of coliform bacteria. It can be suggested that increased integrity of the intestinal tract associated with a greater mucosa, muscle layer, serosa, and total length of intestine after whey and sumac supplementation resulted in improved performance and carcass traits of female broiler chicks.

Acknowledgements. The authors sincerely acknowledge the help provided by the veterinary clinic staff of Shahrekord branch, Islamic Azad University, Shahrekord, Iran.

Edited by: K. Wimmers

Reviewed by: three anonymous referees 


\section{References}

Aghaei, A., Tabatabaei, S., Chaji, M., and Nazari, M.: Effects of Dried Whey (Probiotic) and Probiotics in Laying Hen's Performance and Intestinal Flora, J. Anim. Vet. Adv., 9, 1996-2000, 2010 .

Ashgan, F. E. and Samah, H. M.: Impact of symbiotic on the immune response of broiler chickens against NDV and IBV vaccines, Global J. Biotech. Biochem., 6, 186-191, 2011.

Beard, C. W.: Serological procedures, in: Laboratory manual for the isolation and identification of avian pathogens, edited by: Purchase, H. G., Asp, L. H., Domermuth, C. H., and Pearson, J. E., American Association of avian pathologists, 3, 192-200, 1989.

Chung, C. H. and Day, D. F.: Efficacy of Leuconostoc mesenteroides (ATCC 13146) Isomalto oligosaccharides as Poultry Prebiotic, Poult. Sci., 83, 1302-1306, 2004.

Downes, F. P. and Ito K.: Compendium of Methods for the Microbiological Examination of Foods, American Public Health Association Inc, Washington DC, USA, 2001.

Dughera, L., Elia, M., Navino, C., and Cisaro, F.: Effects of symbiotic preparations on constipated irritable bowel syndrome symptoms, Acta Biomed., 78, 111-116, 2007.

Ellefson, R. D. and Garaway, W. T.: Lipids and lipoproteins, in: Fundamentals of clinical chemistry, edited by: Tietz, N. W., Saunders, W. B. Company, 1967.

Fairchild, A. S., Grimes, J. L., Jones, F. T., Wineland, M. J., Edens, F. W., and Sefton A. E.: Effects of hen age, Bio-Mos and Flavomycin on poult susceptibility to oral Escherichia coli challenge, Poult. Sci., 80, 562-571, 2001.

Fuller, R.: A review: Probiotics in man and animals, J. Appl. Bacteriol., 66, 365-378, 1989.

Ghasemi, R., Faghani, M., Poor Reza, J., Khonmirzaiee, N., and Rahimian Y.: Using Sumac (Rhus coriaria L) extract affect performance and intestinal characteristics of broiler chicks, Schol. J. Agric. Sci., 4, 442-445, 2014.

Golzadeh, M., Farhoomand, P., and Daneshyar, M.: Dietary Rhus coriaria L. powder reduces the blood cholesterol, VLDL-c and glucose, but increases abdominal fat in broilers, S. Afr. J. of Anim. Sci., 42, 398-405, 2012.

Greathead, H.: Plants and plant extracts for improving animal productivity, Proc. Nut. Soc., 62, 279-290, 2003.

Guvenc, A. and Koyuncu, M.: A study on the main active compounds of leaves and fruits of Rhus coriaria L, Turk. J. Medi. Sci., 20, 11-13, 1994.

Hosseini mansoub, N.: Effect of different levels of Sumac Powder (Rhus Coriaria L.) on performance, carcass and blood parameters of broiler Chickens, Ann. Biol. Res., 2, 5, 647-652, 2012.

Jung, N. C.: Biological activity of urushiol and flavanoid from Lac tree (Rhus verniciflua Stokes), $\mathrm{PhD}$ Thesis Chonnam National University, Kwang-Ju, South Korea, 1998.

Kurucu, S., Koyuncu, M., Guvenc, A., Baser, K. H. C., and OZEK, T.: The essential oil of Rhus coriaria L. (sumac), J. Essent. Oil Res., 5, 481-486, 1993.

Langhout, P.: New additives for broiler chickens, World PoultryElsevier, 16, 22-27, 2000.

Majewska, T., Pudyszak1, K., Kozłowski, K., Bohdziewicz, K., and Matusevičius, P.: Whey and lactic acid in broiler chickens nutrition, Vet. Zootec., 47, 56-59, 2009.
Miles, R. D., Butcher, G. D., Henry, P. R., and Littell, R. C.: Effect of antibiotic growth promoters on broiler performance, intestinal growth parameters, and quantitative morphology, Poult. Sci., 85, 476-485, 2006.

Ozcan, M. M. and Haciseferogullari, H.: A condiment [sumac (Rhus Coriaria L.) fruits]: Some physico-chemical properties, Bulg. J. Plant Physiol., 30, 74-84, 2004.

Panda, A. K., Rao, S. V. R., Raju, M. V. L. N., and Sharma, S. R.: Dietary supplementation of Lactobacillus sporogenes on performance and serum Biochemico - lipid profile of broiler chicken, J. Poult. Sci., 43, 235-242, 2006.

Rada, V., Siroteand, K., and Petr, J.: Evaluation of selective media for bifidobacteriablackbox in Poultry and rabbit cecal samples, J. Vet. Med., 46, 369-373, 1999.

Rafiee, A., Kheiri, F., Rahimian, Y., Faghani, M., Valiollahi, M., and R. Miri, Y.: The effect of ginger root (Zingiber officinale) and cumin (Cuminum cyminum) powder on performance, some hematological traits and intestinal morphology of broiler chicks, Res. Opin. Anim. Vet. Sci., 4, 96-100, 2014.

Rayne, S. and Mazza, G.: Biological activities of extracts from sumac (Rhus spp.): a review, Plant Food Hum. Nutr., 62, 165175, 2007.

Rezaian, M.: Modification of fixation process in avian histologic sections, J. Histotechnol., 29, 123-127, 2006.

Ross: Ross 308 Broiler: Nutrition Specification, Ross Breeders Ltd: New Bridge, Midlothian, Scotland, UK, 2007.

SAS Institute: SAS System for Windows. Version 9.1.2, SAS Institute Inc., Cary, NC, USA, 2004.

Samanya, M. and Yamauchi, K.: Histological alterations of intestinal villi in chickens fed dried Bacillus subtilis var. natto, Comp Biochem. Phys. A., 133, 95-104, 2002.

Shariatmadari, F. and Forbes, J. M.: Performance of broiler chickens given whey in the food and/or drinking water, Brit. Poult. Sci., 46, 498-505, 2005.

Spring, P., Wenk, C., Dawson, K. A., and Newman, K. E.: The effects of dietary mannan-oligosaccharides on cecal parameters and the concentrations of enteric bacteria in the ceca of salmonella-challenged broiler chicks, Poult. Sci., 79, 205-211, 2000.

Szczurek, W., Szymczyk, B., Arczewska-Włosek, A., Józefak, D., and Alloui, M. N.: The effects of dietary whey protein concentrate level on performance, selected intestinal tract and blood parameters, and thiobarbituric acid reactive substances in the liver and breast meat of broiler chickens, J. Anim. Feed Sci., 22, 342353, 2013.

Yang, Y., Iji P. A., Kocher, A., Mikkelsen, L. L., and Choch, M.: Effects of mannan oligosaccharide on growth performance, the development of gut microflora, and gut function of broiler chickens raised on new litter, J. Appl. Poult. Res., 16, 280-288, 2007.

Zanoni, S., Pompei, A., Cordisco L., Amaretti, A., Rossi, M., and Matteuzzi, D.: Growth kinetics on oligo- and polysaccharides and promising features of three antioxidative potential probiotic strains, J. Appl. Microbiol., 105, 1266-1276, 2008.

Zavaragh, F. M.: Influence of garlic and sumac powder (Rhus coriaria L.) on performance, carcass and blood biochemicals of Japanese quails, Ann. Biol. Res., 2, 542-545, 2011. 